\section{AMERICAN ETHNOLOGY.}

$\mathrm{IT}$ is with melancholy interest that we receive the nineteenth annual report of the Bureau of American Ethnology, as this was the last report that was edited by the late director; Major Powell's name for so many years has been associated with the publications of the bureau which he initiated that the two have come to be irresistibly associated in our minds. We can only say that his last report fully maintains that high standard to which he has accustomed us.

Sociologists as well as ethnologists will be interested in Mr. James Mooney's historical study of the Cherokee, forming part i. of the nineteenth report. 'The title "Myths of the Cherokee" is misleading, as the memoir includes oral and documentary history, legendary history, legends and myths, with a valuable appendix of notes and parallels to the myths. The true history of Sequoya, the inventor of the Cherokee alphabet, is given, and the remarkable effect of this innovation on the Cherokee nation is admirably sketched, but the promise of progress was ruthlessly destroyed by the action of the Georgia Legislature. In the temperate language of a scientific historian, Mr. Mooney narrates the invariable fate of a native population when the white man wants his country, and now the five civilised tribes are meditating wholesale removal from the Indian territory where they are still being harassed. There seems a determined purpose on the part of many full-bloods to emigrate either to Mexico or South America, and there purchase new homes for themselves and families.

The second part of the report contains one or two studies of the Hopi, or Moqui, Indians of Arizona. These pueblo Indians are among the few surviving tribes of American aborigines which still retain an ancient ritual that is apparently unmodified by the Christian religion. The importance of a careful investigation of these people is fully realised by American anthropologists, and the bureau has in Dr. J. Walter Fewkes a trained observer of the first rank. It is impossible to interpret the Hopi ritual without a clear idea of the present relationship between the existing clans and of their connection with the religious societies. The growth of the ritual has increased with the successive addition of new clans to the pueblo, and its evolution cannot be comprehended without an understanding of the social development and clan organisation of the pueblo. Appreciating this, Dr. Fewkes deals with Tusayan migration traditions, and unravels the history of the accretion of the clans into a community. The localisation of these clans in various pueblos is described by Cosmos Mindeleff, and mapped in several plans; the localisation of clans was rigidly enforced in ancient times, but it is now breaking down. May we suggest to American workers in the field that valuable sociological results would be obtained if they adopted genealogical methods devised by Dr. Rivers (Journ. Anthrop. Inst., xxx., rgoo, p. 74). Dr. Fewkes also gives some details of the famous Snake dance; this dance was primarily a part of the ritual of the Snake clan, and ancestor worship is very prominent in it, indeed, Dr. Fewkes suggests it is "totemistic ancestor worship." There still remain to be investigated various episodes and the sacred songs. The Flute ceremony, which lasts for nine days, is one of the most complicated in the Hopi ritual. Three elements appear to be prominent in the Flute observance-sun, rain, and corn worship, symbols of which are the most prominent on the altars and their accessories. The same is true of the Snake dance; but in both rites the cultus heroes and clan mothers are special deities to which the supplications for rain and corn are addressed. This is interpreted as a form of totemism in which the ancestors of the clan take precedence. The Sun as the father of all cultus heroes, and the Earth as the mother of all gods, ancestral and otherwise, necessarily form an important part of the worship. The relation between religion and sociology is brought out by the author.

"The Wild Rice Gatherers of the Upper Lakes," by Dr. A. E. Jenks, is a sociological study of great interest and value, and should form a model for other researches sociological economics. The Indians in the wild-rice district exhibited some social aspects that were quite unique. Their superior physique and peaceful disposition were fre- quently spoken of. The wild rice led to the peaceful massing together of various tribes and to love for a common country, but being a precarious food-supply, much progress in culture was impossible to these barbarians.

Other papers in the report are "Mounds in Northern Honduras," by Thomas Gann; "Mayan Calendar Systems" and "Numeral Systems of Mexico and Central America," by Cyrus Thomas. The number 20 is the base of the numeral system of the Mexican and Central American tribes, but it does not appear to have been used as a mystic number in rites. There are other peoples who use the vigesimal system, but no others are known who adopt the twenty-day month or eighteen-month year. We cannot conceive how a twenty-day period could have grown out of a lunar count; probably two time systems, a secular and a sacred one, were in use at the same time, and the latter finally obscured the former. The author's conclusion is that the priests adopted a method of counting time for their ceremonial and divinatory purposes which would fit most easily into their numeral system, and this system, in consequence of the overwhelming influence of the priesthood, caused the lunar count to drop into disuse. Prof. W. J. McGee publishes a characteristic essay on "Primitive Numbers." The memoirs in these two volumes are copiously illustrated with numerous excellent plates, some of which are coloured.

A. C. H.

\section{AGRICULTURAL NOTES.}

FROM a recent number of a Scotch agricultural newspaper it appears that the Earl of Rosebery has a private station for agricultural research on his home farm near Edinburgh, but the gratification which this information might otherwise have afforded is tempered by a perusal of an account, given by the newspaper, of a visit paid by a party of agriculturists to the place. The experiments, we gather, have been in existence for several years, but no reports on the station's work have been published, and we are left to glean something of its character from the statements made by the estate agent and the district analyst, who respectively represent practice and science in the control of the work. In speeches which are reported at some length, first the agent and then the analyst proceeded to ridicule the work done at other experiment stations. Rothamsted, Woburn, the East of Scotland Agricultural College, and the Highland and Agricultural Society were singled out for condemnation, and one is dismayed to find that "great laughter" was evoked by a quotation of what purported to be the words of the late Sir Henry Gilbert, whose fifty years' devoted service has earned the respect of all right-minded agriculturists. The claims made for Dalmeny-the experiment station-were as amusing as the references to others, were offensive. We hear, for example, that " the Dalmeny station was the only agricultural experiment station in the world where the research work was carried out on biological lines," and that "if imitation was the sincerest form of flattery, Dalmeny had been very sincerely flattered of late years, for so-called new lines of investigation were being taken up and books were being written which were simply plagiarisms of Dalmeny work and its results." Until some change is made in the management of Dalmeny experiment station it is clear that no serious consideration need be given to the work being done there.

For the past three years Mr. S. H. Collins, agricultural chemist at the Durham College of Science, has been investigating the composition of the Swedish turnip, the chief root crop of the north of England. A large number of varieties have been grown under identical conditions and also under different conditions of soil, climate, and manuring. The work is still in progress, but certain conclusions which have been come to are stated in the eleventh report of the college agricultural department. They are (i) the higher the percentage of dry matter in swedes the greater the feeding value; (2) swedes are very variable in composition, and not less than fifty roots should be sampled for the purpose of analysis; (3) the average composition of some varieties is much better than that of others ; (4) the varieties which are best at one farm will also be best at

NO. I 766, VOL. 68] 
other farms; (5) next to variety, season, and then soil, most affect the composition of swedes; the influence of manuring is not marked. The fourth conclusion is warranted by the facts which Mr. Collins brings forward, but this point is one on which further information is wanted, for it seems probable that the relative position of different varieties might change if the varieties were exposed to markedly different conditions.

A Bulletin reciently issued by the U.S. Department of Agriculture, entitled "The Mango in Porto Rico," discusses the prospects of mango cultivation on the island. Porto Rico grows mangoes in abundance; the climate is very favourable, and the trees are free from disease, but hitherto scedling trees only have been grown, and one is not surprised to read that the mangoes have met with but little favour in the American markets. The fame of the Bombay mango is due to the fruit of grafted trees, and it is rarely that trees raised from seed produce fruit worth eating. Seedling trees abound in every village, but firstrate trees are very uncommon. The short list given in Woodrow's "Gardening for India " shows how rare really good seedlings are. When the Americans import fine strains and take to growing grafted mango trees the industry is certain to make rapid progress. We gather from the' Bulletin that this subject is likely to engage the attention of the local experiment station. We hope it may, for if the matter is taken up with the energy characteristic of the American stations, there is every prospect of a great increase in the supply of the finest of tropical fruits.

\section{REPORT OF THE MALARIA EXPEDITION TO THE GAMBIA.}

THE Liverpool School of Tropical Medicine has just issued a most important and practical report upon the prevention of malaria in the tropics. ${ }^{1}$ Dr. Dutton, who conducted the expedition with conspicuous success, shows with striking clearness how a great deal of disease is due to the want of knowledge of the nature of malaria, and that during the dry season the residents are largely to blame for the appearance of the disease. It is one of the most hopeful reports ever issued by the school, and it shows that the governors and others in authority upon the coast are fully alive to the importance of stamping out malarial diseases. The report is an immense step forward in preventive medicine.

The object of the expedition was to investigate the conditions under which mosquitoes were propagated in the town of Bathurst and at the principal stations of the colony, and to suggest methods of destroying these insects. Malaria was found to be prevalent in the colony; 80 per cent. of the native children examined harboured malaria parasites in their blood. The liability to infection of the Europeans commences soon after the rains are established, lasting up to the end of November. The various breeding places of inosquitoes are described in detail in chapter iv, of the report, particular mention being made of the wells, canoes, boats, lighters, cutters on the foreshore, and of the grass-clogged trenches in many of the streets, which together supply Bathurst with the majority of its mosquitoes during the wet season and for part of the dry season. The number of mosquito breeding places present in compounds was found to vary with the social position of the occupier. They increased in extent and number in proportion to the wealth and position of the occupier.

An account of the examination of one of the large compounds illustrates to what extent mosquitoes are bred by the white man in the tropics on his own premises.

In one factory yard were found six barrels, and in the garden there were seventeen tubs and eight small wells, all breeding quantities of Culex, Stegomyia, and Anopheles mosquitoes. Besides these dry season breeding places, discarded domestic utensils were scattered about the yard and garden which, in the wet season, would have acted as breeding places. It is pointed out that during the dry season, from November to May, natural breeding places for 1 "Report of the Malaria Expedition to the Gambia, rgoz, of the Liverpuol School of "Tropical Medicine and Medical Parasitology." By J. F.

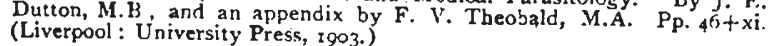
No. 1766 , voL. 68$]$ mosquitoes in Bathurst cease to exist, and from this period the people breed mosquitoes solely in their own compounds.

In chapter v., which deals with the prevention of malatia in Bathurst, a campaign against the mosquito is advocated the town is judged especially suitable for its success. Thus Bathurst is situated on a practically isolated piece of land surrounded on nearly all sides by a broad expanse of sea water. The amount of land to be dealt with is comparatively small, viz. about a square mile. The surface is fairly level, sandy, absorbing water readily. In this area the breeding places of mosquitoes are a known quantity, the artificial, or those made by man, being in excess of the natural. The rainfall is very small, and rain occurs only during four out of the twelve months of the year.

The probability of the introduction into Bathurst of yellow fever from Senegal is pointed out as another reason for attacking the mosquito. The expedition was informed by $\mathrm{His}$ Excellency the acting Governor, H. M. Brandford Ciriffith, of the intention on the part of the Colonial Government to enter upon a crusade against the mosquito, and on November is the preliminary removal of rubbish from houses and compounds began; a sanitary inspector was appointed, and received special instruction in the work. Lnder him worked a gang of labourers, and at the time of the departure of the expedition (January 10) 363 houses and compounds had been inspected. From these I3I cartload. of old tin pots and other rubbish were removed. On the return of His Excellency the Governor, Sir George C. Denton, the inspector and a sufficient staff of labourers were appointed permanently, and a grant of $200 l$. per annum was given for the special anti-mosquito work. Antimosquito regulations have been drawn up by the Colonial Government. These are given at the end of the report:

An apnendix, by Mr. F. V. Theobald, is attached to the report; in it are described the various species of mosquitoes collected by the expedition, many of which were new to sciense.

\section{ZONES IN THE CHALK.}

IN Nature for August 8,1901 , attention was directed to the second part of Dr. A. W. Rowe's researches on the zones of the White Chalk. We have now had the satisfaction of receiving the third part of this most interesting and important work, which deals with the Chalk of Devon (Proc. Geol. Assoc., vol. xviii. part i., I903).

Working the palacontology with such aids as can be gathered from the local stratigraphy and lithology, the author, assisted as before by Mr. C. D. Sherborn, has added extensively to our knowledge of the successive forms of life that are met with in the Chalk between Sidmouth and Lyme Regis. Whether or not the limits of the zones happen to coincide with definite stratigraphical limits, these latter afford useful data, and one marl band to which the author directs special attention, forms the plane of division between the zones of Terebratulina gracilis and Holaster planus. Such definite and continuous bands of rock (so far as they can be traced) must afford even more precise evidence of contemporaneity than the presence of this or that fossil. Even a tabular flintband has proved " an almost constant feature throughout the coast "--an interesting fact, and one that was not to bo expected. It is admitted that the name-fossils are not always confined to their zones. Holaster planus is found by Dr. Rowe throughout the zone of Terebratulina gracilis. But the guide-fossils, the general assemblages associated with the name-fossils, while they exhibit here, as elsewhere, local variations, tell the same story of the successive zones or stages of life, and indicate their approximate limits. Perhaps too much importance is given to the effort to fix a precise divisional plane between zones. When such divisions depend on the forms of life, and the succession of life is continuous though gradually varying, there can be no absolute planes of division, except through the absence or erosion of strata belonging to a particular perind of time.

The work before us is rich in its stores of interesting facts. The zone of Rhynchonella Cuvieri presents noteworthy features in the presence of Micraster cor-bovis and $M$ leskei, the zone of Terebratulina gracilis is "singulariy rich in fossils," while in the zones of Holaster planus and 